\title{
PROJECT OF RECOVERY THE BIOLOGICAL CONDITIONS OF THE PRODUCTION SYSTEM IN SALTWORKS OF INDUSTRIA SALINERA DE YUCATAN S.A. DE C.V. (ISYSA) DAMAGED BY THE HURRICANE ISIDORE IN SEPTEMBER OF 2002
}

\author{
S.M. ORTIZ-MILÁN
}

\author{
Industria Salinera de Yucatán S.A. de C.V., \\ Ecology Department \\ Calle 1-H - 105 int. 19 Col. México Norte, \\ Merida, Yucatán, México C.P. 97125
}

Received: 19/08/08

Accepted: 20/10/08 *to whom all correspondence should be addressed: e-mail: sortiz@isysa.com.mx

\begin{abstract}
Industria Salinera de Yucatan S.A. de C.V. (ISYSA) has its operation of primary production of salt by solar evaporation in Las Coloradas, Yucatan, Mexico, in the coast the northwest of the Yucatan Peninsula. One of the disadvantages of this location is the presence of extreme climatologic phenomena like hurricanes, since they put in risk the stability of the lagoons of production by the thin coastal dune strip that delimits the ocean with the evaporation ponds.

In September of 2002 the Isidore hurricane hit the coasts of Yucatan, and although the eye of the hurricane was at 70 kilometers to the north of the coasts of Las Coloradas, the damages that it caused to the production system were considerable. This climatologic phenomenon opened to a channel between the sea and the area of evaporation ponds, allowing that the force of the water intercommunicated to several ponds when losing itself the dikes. The salinity gradients were modified as well as the microbiological component of the evaporators when coming off itself the upper layer of benthic microorganisms with the force of the surge, facilitating the increase of populations of microalgae Aphanothece halophytica that forms a mucilage substance that affects the quality of brines.

One of the works was the introduction of great amounts of brine shrimp in the evaporation ponds. The work focused in the design of a continuous culture and great production of brine shrimp in suitable facilities to make adequately these works, as well as the culture of great concentrations of the microalgae Dunaliella viridis like live food for the cultures of brine shrimp. On the other hand, 18 fiber glass carboys with capacity of 800 liters each one, is prepared with brine of the crystallizers with $25^{\circ} \mathrm{Be}$ mixed with fresh water and the content of the culture of Dunaliella viridis. The fiber glass containers that already have the concentration adapted of brine shrimp to be introduced to the evaporation ponds previously selected.
\end{abstract}

These actions have taken to fortify the community of brine shrimp in the evaporating ponds with intermediate and high salinity and therefore to improve the brines with total transparency and a stability between the communities of the ponds and the diminution of the Aphanothece halophytica in the brines.

KEYWORDS: Brine, crystallizers, salt ponds, Aphanothece halophytica, Dunaliella viridis, evaporators, benthonic community, planktonic community, brine shrimp culture.

\section{INTRODUCTION}

The salt production system of ISYSA, is located in the coast the northwest of the Yucatan Peninsula, this location favors the suitable evaporation of the brine for the precipitation of the mineral of excellent quality. The facilities comprise the coastal bar that delimits the Gulf of Mexico to the north with the coastal lagoon (ría) from Rio Lagartos to the south, where the 
water for its evaporation is extracted. The coastal lagoon has a length of approximately 80 kilometers and one amplitude that varies of 100 meters to 4 kilometers wide with an approximated volume of $50 \times 10^{6} \mathrm{~m}^{3}$, and a depth average of $0.7 \mathrm{~m}$ (SEMARNAP, 1999) (Figure 1). The ría has direct communication with the sea in a point near the Rio Lagartos village. These hydrological characteristics of the ría cause that the water flow is very slow allowing that the evaporation is much greater to the water contributions towards this lagoon, maintaining salinity above of the sea water. In general the geographic location of the ISYSA facilities depends in good part of the meteorological conditions, mainly those that by their intensity can cause damages in the operational structure of the salt mine.

The most recurrent and great intensity phenomena are the hurricanes. This region of the Gulf of Mexico like the Caribbean Sea, it has a direct influence of the hurricane formation in the Atlantic Ocean, having in the last 20 years most intense reported. In 1988 the Hurricane Gilbert touched the coasts of Yucatan, causing a deterioration of great importance for ISYSA, beginning a development of the investigation in the biological behavior of the salt production.

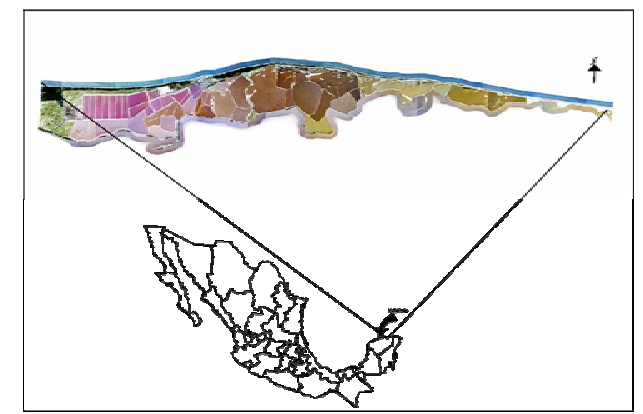

Figure 1. Las Coloradas Saltworks

In 2002, the hurricane Isidore affect again the facilities of salt production, causing the opening of a channel of 300 meters between the ocean and the lagoons of evaporation generating a decompensation in the salinity gradient, as well as in the microbiological component. From these problems, the main action was to assess the damage caused to the different communities of benthonic and planktonic microorganisms of the lagoons to determine a plan of systematic work for the regulation of the system, as well as the elimination of great amount of organic matter contributed by sea and the ría of Rio Lagartos. One of the most important results was the increase in the population of the seaweed Aphanothece halophytica as well as the seaweed Aphanocapsia, where both have the faculty to reproduce taking advantage of the chemical, physical and biological destabilization of the evaporation ponds diminishing the quality of brines.

Knowing the brine shrimp qualities, the first step was to improve the program for its reproduction, because it is an organism that has the characteristics to carry out the actions of diminution of the organic matter in brines (including organic particles, inorganic and seaweed). The approach of this work is based on the used methodology to carry out this reproduction of brine shrimp to laboratory level, as well as of its main alive food, the Dunaliella viridis seaweed that it was taken and isolated from the brines and that does not have a negative impact in the quality of the brines and it has a great acceptance by the brine shrimp. The results in the medium term were flattering as far as the diminution of the organic matter in brines and the maintenance of a healthful population of brine shrimp in lagoons of medium salinity, as well as in the stabilization of the different groups of organisms in the salt ponds (Davis, 1990).

\section{CONDITIONS BEFORE HURRICANE ISIDORE}

The conditions reached in 2000 to 2001 in the saline system, were best later to the passage of the hurricane the Gilberts in 1988; during this period a detailed pursuit of the recommendations emitted by Dr Joseph Steven Davis, professor of the University of Florida and consultant of Industria Salinera de Yucatan S.A. of C.V. (ISYSA) for the assessing of the biological and productive system. On the basis of the annual reports prepared by the Dr. Davis, works in the handling of production brines were diverse, such as the adequate handling of the levels of depth of brines, as well as its rest times in each one of the ponds. On the other hand, in these years an important impulse occurred to improve the conditions of the Laboratory of Biology of ISYSA to improve the reproduction of brine shrimp and its later inoculation in field. 
One of the clearest and important objectives statements in the reports of the Dr. Davis is to diminish the amounts of the seaweed Aphanothece halophytica due to the characteristics to form massive congregations of organic matter in form of mucilage very difficult to eliminate in brines and that causes serious damages to the salt production (Baha Al-Deen and Baha AlDeen, 1972). This objective was reached in the 2001 when the amounts of the seaweed reached zero in the previous lagoons from evaporation at the crystallization stage, allowing an improvement in the quality of the brine and as well in the harvested salt.

\section{METHODOLOGY FOR THE BRINE SHRIMP REPRODUCTION}

\subsection{Dunaliella viridis like live food}

Culture Medium Preparation. Medium A was prepared in fiberglass tubs, each $1.2 \mathrm{~m}$ diameter at the rim, $1 \mathrm{~m}$ deep, and $1 \mathrm{~m}$ diameter at the base by mixing brine of $\mathrm{Be} 25$ from a crystallizer pond of the salina with freshwater to obtain 600 liters of liquid at Be 18. To kill most organisms, $3 \mathrm{~g}$ of sodium hypochlorite were dissolved in each tub and neutralized two hours later with $1 \mathrm{~g}$ sodium thiosulfate. Fifteen $\mathrm{g}$ of dry fertilizer whose assay was $30 \% \mathrm{~N}$, $30 \% \mathrm{P}, 30 \% \mathrm{~K}$ (Agro Mex SA de CV) and one lozenge of Theragran y Minerals (BristolMyers-Squibb) composed of vitamins A, B1, B2, B6, B12, C, D3, E, niacinamide, and trace quantities of $\mathrm{FeSO}_{4}, \mathrm{KCl}, \mathrm{CuSO}_{4}, \mathrm{MgSO}_{4}$, and $\mathrm{ZnSO}_{4}$ were dissolved in each tub. The tubs were placed outdoors under a shade cloth that attenuated $80 \%$ of the light reaching the cultures.

Culture of Dunaliella viridis. A stock culture was started with a single $D$. viridis cell isolated from a production pond of the ISYSA salina, placed in Medium A, and allowed to grow under fluorescent tubes at $20^{\circ} \mathrm{C}$. Twenty-liter glass or plastic carboys filled with Medium A were inoculated with the stock culture, continuously sparged with air, and placed outdoors under the shade cloth. The inoculated carboys remained outdoors under the shade cloth until concentrations of 350 to $450 \times 10^{4}$ cells per $\mathrm{ml}$ of $D$. viridis were reached (See Figure 2).

\subsection{Brine shrimp reproduction and inoculation.}

Culture of Artemia. From each fiberglass tub twenty $L$ of Medium $A$ were withdrawn and replaced with the contents of one $20 \mathrm{~L}$ carboy containing 350 to $450 \times 10^{4} \mathrm{D}$. viridis per $\mathrm{ml}$ and then sparged continuously with air. After $D$. salina reached concentrations of 350 to $450 \mathrm{x}$ $10^{4}$ cells per liter ( 5 to 6 days), 50 pairs of Artemia were then placed in each tub. (A stock culture started with Artemia from a production pond and fed with $D$. salina provided the pairs.) Each day thereafter a $20 \mathrm{~L}$ carboy containing 350 to $450 \times 10^{4} \mathrm{D}$. viridis per $\mathrm{L}$ was placed in each tub and $20 \mathrm{~L}$ of liquid withdrawn from which the Artemia were temporarily removed with mesh nets. The Artemia were then replaced into the tubs (See Figure 3).

Reintroduction of Artemia to Production Ponds. The Artemia maintained in the tubs grew until they attained lengths of 8 to $10 \mathrm{~mm}$. Twice each week during January 2003 through December 2003, the animals were removed from the tubs with mesh nets, transferred to Styrofoam boxes containing Medium A, transported to the field, and emptied near the intake of selected intermediate salinity (Be 10 to $\mathrm{Be} 19$ ) ponds. Although shore birds and flamingoes occasionally foraged in the peripheries and shallow areas of these ponds, predation on the brine shrimp population was insignificant.

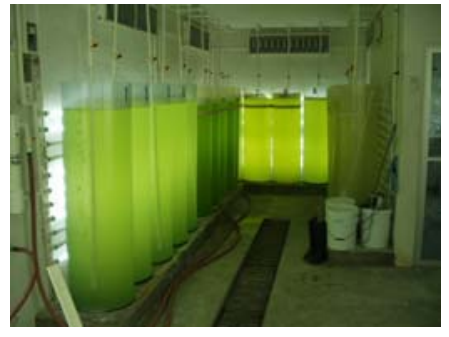

Figure 2. Fiber glass carboys for Dunaliella viridis reproduction

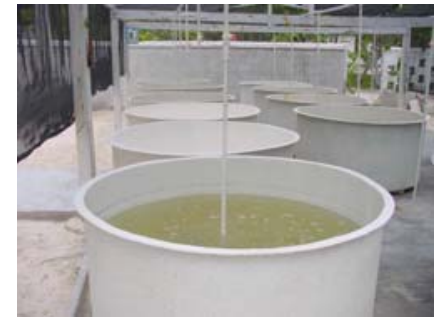

Figure 3. Fiber glass carboys for Artemia reproduction 
Monitoring Methods of the Artemia Project. Monday through Friday measurements in selected ponds along the salinity gradient near sampling sites permanently marked with depth stakes included light extinction determined by a Secchi disk, salinity with a hydrometer calibrated in degrees Baume, and temperature in degrees centigrade. From water samples collected at the sampling sites, concentrations of Aphanothece halophytica and other plankton were determined with a hemocytometer. Water of all ponds was examined by using 10X and 40X objectives of a compound microscope. Concentrations of Artemia in the production ponds were determined by counting the nauplii and adults of the animals in samples of water in a $500 \mathrm{ml}$ graduated glass cylinder collected at the sampling sites.

Prior to our reintroductions of Artemia, water in ponds was turbid with planktonic organisms; mean concentrations of Aphanocapsa and Aphanothece halophytica (the dominant organisms) remained near $70 \times 10^{4}$ cells per liter during most months. In ponds inoculated with Artemia, concentrations of Aphanothece halophytica and Aphanocapsa decreased and water transparency increased shortly after the first reintroductions. These concentrations and transparencies remained unchanged during 2003. In the water column, concentrations of Dunaliella viridis were estimated at less than 1 cell per $10 \mathrm{~L}$; at the bottom-water interface, $D$. viridis cells were well represented. In May 2003 the mucilaginous benthic communities of 2 layers covered large areas of the floors in all but the deepest parts of the ponds. In the intermediate salinity ponds, the uppermost layer was pale green, and dominated by Aphanothece halophytica. Phormidium, ciliates, flagellates, and a variety of bacteria were also present. The lowermost layer contained organisms similar to the uppermost, but Chromatium was also well represented. In the same ponds, the uppermost orange layer was a thin gypsum crust above mucilage dominated by Aphanothece halophytica, and the lowermost green layer contained mucilage, A. halophytica, Phormidium, Chromatium, and Beggiatoa. Fecal pellets of brine shrimp gathered from the floors of ponds inoculated with Artemia contained dead and discolored $A$. halophytica, fragments of planktonic organisms, and numerous microscopic gypsum crystals. Many fecal pellets had become incorporated in the crusts and uppermost layers of the benthic communities. No evidence of Dunaliella viridis cells was observed in the fecal pellets of Artemia gathered from the pond floors.

\section{RESULTS}

\subsection{Laboratory of brine shrimp culture}

The necessity to increase the amount of brine shrimp for the inoculation works in the ponds, make some improvements in the facilities and in the equipment in the Laboratory of Biology of ISYSA, it was required for the implementation of a series of procedures, as well as a program of qualification to the operative personnel to have a ampler knowledge of the diverse areas of the laboratory to improve the workings of itself.

The volumes of production of brine shrimp for the inoculation in ponds in 2003 were approximately 450 million organisms between adults, juveniles and nauplii, which represent approximately 400 kilos of brine shrimp in wet weight. The production of brine shrimp in the 18 carboys of 1.000 liters was made of sequence way to make one inoculation per day of the total content of one of these carboys. The months of greater production went from May to September.

\subsection{Field improvements}

The inoculation of brine shrimp in ponds with adequate chemical and physical characteristics was a constant work mainly in the months of greater temperature and minor precipitation. The inoculations were carried out in two different forms: first, by means of the direct inoculation in pond brines, and second, in cages made with a special textile that allows the flow of the brine, but it does not allow that brine shrimp escape and that is attacked by possible predators.

The inoculation in cages allowed to know the adaptation process of the organism in the brines of the ponds and to determine an approximated mortality rate, being this of $23 \%$ in average for the period of more constant inoculation (May - September). The efficiency of the adaptation of brine shrimp in brines was reflected in the diminution of the organic matter and 
mainly in the gradual diminution of the seaweed Aphanothece halophytica as it is appraised in Figure 4.

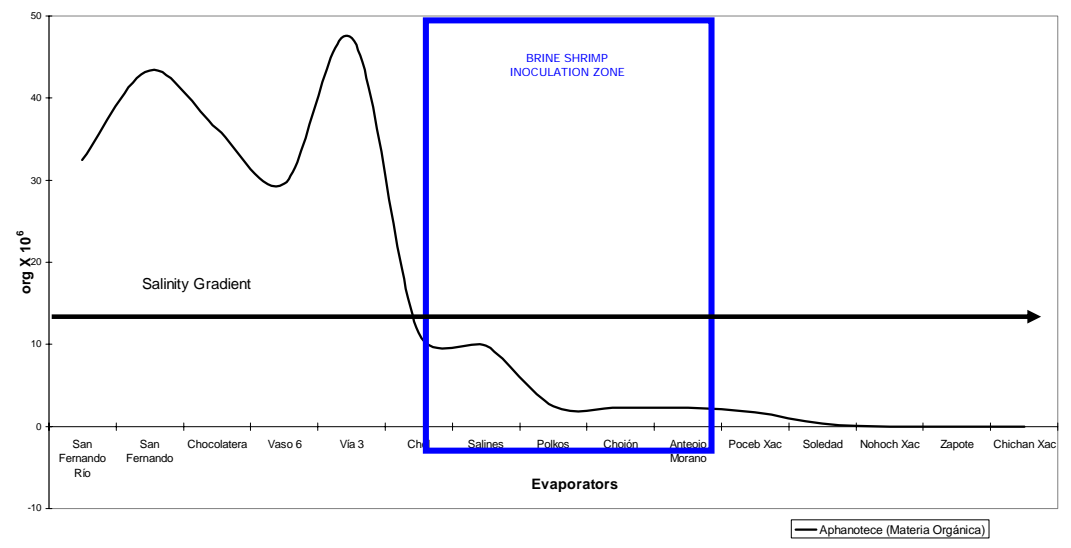

Figure 4. Diminution of Aphanothece halophytica in salt ponds

Due to the constant brine flow towards the zone of crystallization, the inoculations of brine shrimp are constant within the same zones, because many organisms lose by this effect of movement of brines towards the zone of salt production. One of the most important characteristics reached in this stage of maintenance of the populations of brine shrimp is the difference in the transparency of brines in the evaporation ponds that is the group of ponds that feed the crystallizers, where a total transparency was reached like a final result.

\section{CONCLUSIONS}

One of the most important actions in the recovery of the biological conditions in salt ponds where the characteristics are the interaction of diverse groups of microorganisms; is the knowledge of its behavior throughout the gradient of salinity of brines, as well as its distribution and its possible affectations to the production area.

Brine shrimp is an organism helpful for the control of other groups of microorganisms that destabilize the saline system (Tackaert and Sorgeloos, 1993) reason why its reproduction, inoculation, maintenance and evaluation are an adequate project to reach the objectives of a solar salt company: obtain an excellent quality of brine for the production of the mineral.

\section{REFERENCES}

1. Davis J.S., (1990) Biological management for the production of salt from seawater. In: J. Akatsuka (ed), Introduction to Applied Phycology. SPB Academic Publishing, The Hague, 479488.

2. Baha Al-Deen B. and Baha Al-Deen A.H., (1972) Posible efecto de microalgas en la forma de cristalización el cloruro de sodio en la salina de Araya, Bol. Inst. Oceanog. Univ. Oriente, 11, 35-38.

3. Secretaría del Medio Ambiente y Recursos Naturales (1999) Programa de Manejo de la Reserva de la Biosfera Ría Lagartos (SEMARNAP). Instituto Nacional de Ecología. México, $203 \mathrm{p}$.

4. Tackaert W. and Sorgeloos P., (1993). The use of brine shrimp Artemia in biological management of solar saltworks, In: Seventh Symposium on Salt, Vol. 1, pp. 617-622. 